\title{
Transdisciplinarity: science for and with society in light of the university's roles and functions
}

\author{
Roland W. Scholz ${ }^{1,2,3}$
}

Received: 13 April 2019 / Accepted: 2 March 2020 / Published online: 28 March 2020

(c) The Author(s) 2020

\begin{abstract}
The idea that universities should become entrepreneurial, commercialized, private commodities or should serve politicians and governmental agencies has been promoted by the university-industry-government relationship-based Triple Helix approach and is reality in many places. In contrast, a reemphasis on universities serving the public good has been demanded by proponents of transdisciplinary sustainability research. To better understand the tensions between public-good-oriented approaches of transdisciplinarity and entrepreneurial, market-oriented Triple Helix and third-mission approaches of science-practice collaboration, this paper takes a closer look at the history of universities' roles and functions. We then elucidate the practice of transdisciplinary processes and discuss the "science for and with society" approach of transdisciplinary sustainable transitioning. We argue that transdisciplinarity for producing groundbreaking sociotechnical solutions has to serve (a) the public good and (b) calls for independence, academic freedom, institutionalization, and proper funding schemes. Third-mission conceptions that follow the commercialization/capitalization of scientific knowledge are in conflict with the conception of science and of transdisciplinarity serving sustainable transitioning. The development of groundbreaking ideas for sustainable transitions must acknowledge the complexity and contextualization of real-world settings. Therefore, collaboration between practice and transdisciplinarity calls for the input and cooperation of authentic practitioners, i.e., the experts of practice and real wold complexity. The challenge of transdisciplinarity is to properly relate the fundamental expertise of practice to validated academic rigor. This implies that transdisciplinary research is a critical element of the university's research mission.
\end{abstract}

Keywords Transdisciplinarity $\cdot$ Third mission $\cdot$ Science as a public good $\cdot$ Academic freedom $\cdot$ Sustainability entrepreneurship

\section{Transdisciplinarity as a methodology of sustainable development}

In its transition to the postindustrial age, the world faces a multitude of essential, complex, ill-defined problems that are not well understood. From a sustainability perspective, rapid

Handled by Masaru Yarime, ong Kong University of Science and Technology, Hong Kong.

Roland W. Scholz

roland.scholz@emeritus.ethz.ch

1 Department of Knowledge and Information Management, Danube University Krems, Dr.-Karl-Dorrek-Strasse 30, 3500 Krems, Austria

2 Institute for Advanced Sustainability Studies (IASS), Berliner Strasse, 130, 14467 Potsdam, Germany

3 Department of Environmental System Sciences, ETH Zurich, Universitaetstrasse 22, 8092 Zurich, Switzerland climate change, loss of biodiversity, ongoing global-population growth, and seemingly uninterrupted increases in consumption and emissions (Krausmann et al. 2017), as well as the increasing social divide (Dorling 2015) and unintended side effects of digitalization (Bakhshi et al. 2015; Hilbert 2014; Scholz et al. 2018; Sugiyama et al. 2017; Viale Pereira et al. 2020; WBGU 2019), endanger not only resilient Earth structures and systems but also social structure and order.

Conducting science with society is critical if we refer to a systemic view of sustainability (Laws et al. 2004) that conceives of sustainable development as an (1) ongoing inquiry (i.e., a societal process of searches, trade-offs, and negotiations regarding what the problem is and what goals should be attained) into (2) system-limit management (i.e., resilience management to prevent undesirable system collapses) in (3) the frame of fundamental normative and regulative ideas (Kant 1787/1965; Schneidewind et al. 1997). With the latter, the concepts of intra- and 
intergenerational justice gained global acceptance with the UN's 1987 Declaration on Our Common Future (United Nations) (1987).

A key challenge of sustainable development is how (properly proven) scientific knowledge can be developed, used, and linked with other forms of knowledge, in particular, the experiential knowledge of practice experts, in the course of sustainable development. A shift from "science for society" to "science with society" (Klein et al. 2001; Scholz et al. 2000a, b; Scholz and Stauffacher 2009; Seidl et al. 2013) was first promoted about 20 years ago when transdisciplinarity developed as a third mode of doing and utilizing science. In this context, transdisciplinarity was defined as "a new form of learning and problem-solving involving cooperation among different parts of society and academia in order to meet the complex challenges of society" (Häberli et al. 2001, p. 7). Later, the (operational) problem-solving view was replaced by the aim to develop socially robust orientations for undertaking actions (Klein 2004; Scholz et al. 2006) designed to cope with complex, ill-defined, multilayered, and socially relevant systems and dynamics that are often contested by society. Mutual learning among science and society (Scholz 2000), i.e., the relating and integrating of different forms of epistemics, has been seen as a key means of transdisciplinarity (Scholz and Steiner 2015c). Practitioners are considered experts for coping with (contextualized) real-world challenges; scientists are considered experts for validated, method-, theory-, and (partly) evidence-based descriptions of (general) dynamics underlying real-world systems. As sustainable development is a matter of real-world system transitions, not only knowledge but also social values (i.e., drivers) that depend on individual and social systems' interests, values, needs, positions, and roles (Häberli and GrossenbacherMansuy 1998; Siebenhüner 2018) must be included in a balanced manner. Thus, in any sustainability research, there is a normative component (Scholz 2017).

Governmental and societal demands that universities work for society by going beyond their traditional teaching and research missions to visibly contribute to societal and economic problem-solving has been labeled the "third mission" (Gulbrandsen and Slipersaeter 2007; Laredo 2007). The third mission has been "essentially viewed as encompassing the licensing of the outputs of research, and formation of spin-out business ... [and] provision of commercial problem-solving services ..." (Minshall et al. 2004, p. 8). The driver for this has not been sustainable development but the commercialization of university services (Slaughter and Leslie 1999), which may be considered part of the commodification of data and knowledge in the shift to the digital age and technology development in increasingly knowledge-based societies (Etzkowitz et al. 2000).

This paper discusses transdisciplinarity from the view of the university as (non-political) public good. We elaborate on the conception that an unreflected commercialization following of the idea of the (market oriented) third mission contrasts with developing socially robust orientations for sustainable development, in mutual learning processes between science and society and for learning as well as in mitigation in multi-stakeholder discourses. To better understand this, we examine the historical functions and roles of the university, and then reflect on the emergence of transdisciplinarity, the Triple Helix concept, and other forms of science-practice collaboration. The key proposition of the paper is that universities to place too much emphasis on the commercialization of their research as a yardstick for measuring their (overcommercialization of research). Thereby, they lose the freedom of research and the resources needed for the production of groundbreaking generalized, basic knowledge on sustainable transitioning. This is, for instance, required in open transdisciplinary processes directed to maintain the viability of important human and environmental systems. The discussion highlights the mechanisms underlying these developments and the choices universities might make and how the need to serve the public good is linked to sustainable transitioning.

\section{History of universities' roles and functions}

We provide insights into the origins and current changes of roles and functions of universities by a brief historic analysis.

\section{Faculties, degrees, academic freedom, and the knowledge economy}

The university is one of the oldest institution in the Western world. The large number of key features of the first one, the University of Bologna founded in 1088, that remain unchanged is intriguing. The university was organized in faculties ((A2), labels like this refer to Table 1) and awarded performance-based academic degrees (baccalaureate, magister, doctorate) by governmental and/or papal authorization (A1). Students and professors were allowed more freedom of thought and speech than others in society (A3) (Montague 2013), and this academic freedom has been viewed critically by governmental actors and others. Another issue has 


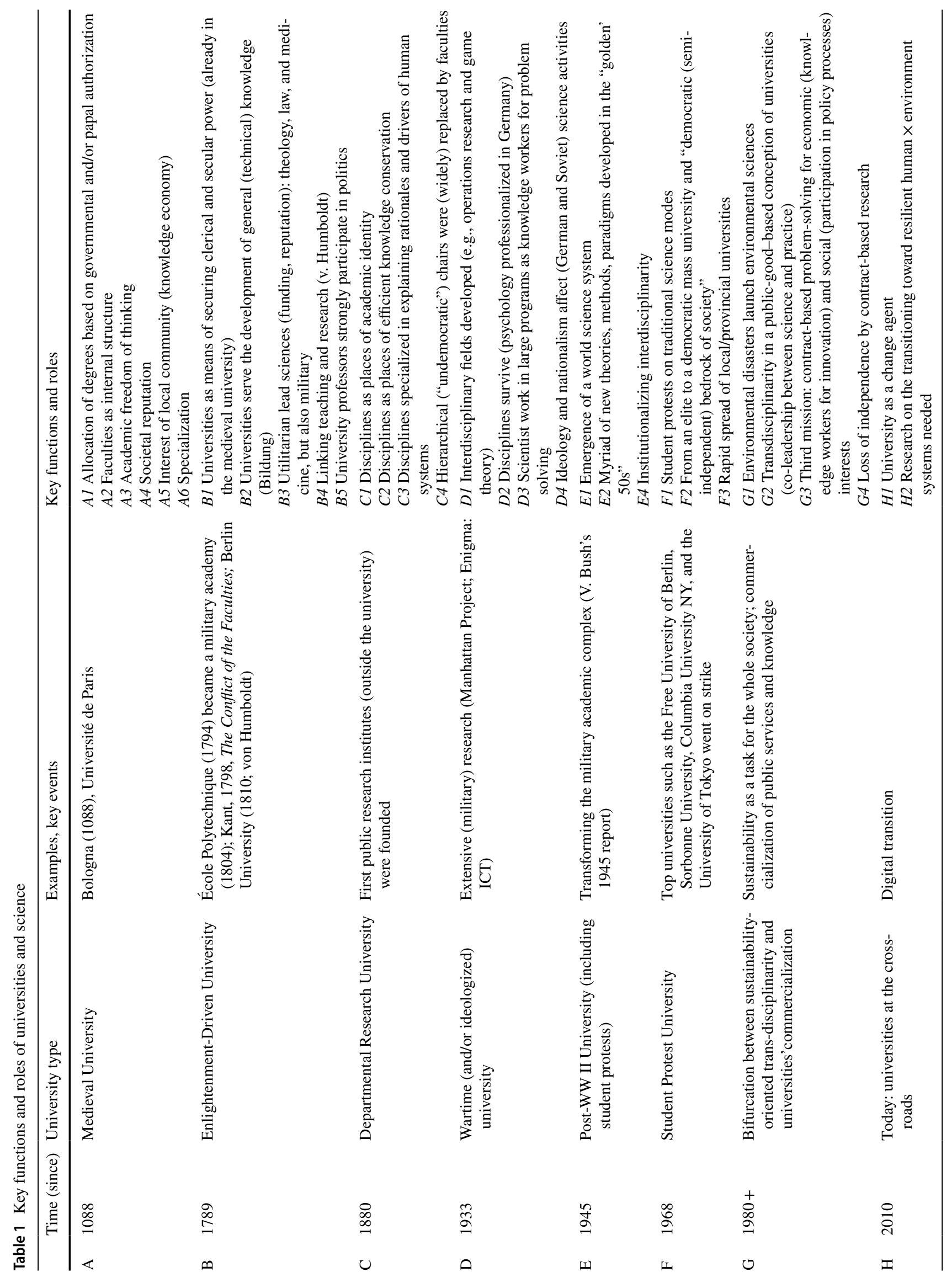


been the knowledge economy (A5); local communities were interested in the reputation of having a university and in students as consumers (A4) (Rashdall 1895). The first universities had already adopted particular profiles, e.g., Bologna in civil and ecclesiastical law and Paris in theology (A6) (Wei 2012). The Church, law, and theological faculties (e.g., Wittenberg for Martin Luther; Paris for Thomas Aquinas) have been seats of power through the teaching of humanistic and religious normative ideas (B1).

\section{From Bologna to the departmental university of teaching and research}

The Bologna conception of the university remained widely unchanged until around the time of the French Revolution. The Conflict of the Faculties by Immanuel Kant (1724-1804) (Kant 1778/1779, 1979/1798) was the cornerstone for the development of science. Kant criticized the strong alliance of the leading sciences (e.g., theology, law, and medicine) with governmental interests as blocking human development (B1); the faculties were downgraded to agents of secular and clerical principles when promoting dogmatic, unreflective, governmental policy and repression supporting (religious) doctrines and censoring deviating ideas. Funding was the means of manipulation. Kant's essay, "What Is Enlightenment?" (Kant 1784/1845), is a plea for the independence of ideas and reason (German: Verstand) and for the primacy of the human mind (German: Geist), which should not be contaminated by social or governmental interests (Klein 2016). In strong agreement with Francis Bacon (1561-1626), Kant argued for reasoning based on evidence and strongly criticized the medical faculty for its schematic fulfillment of duties to the state without courageously searching for a data- and evidencebased rethinking of the genesis of diseases. We should note that not the universities but also institutions such as the Royal Academy of Society (founded 1666), Académie des Science (1666; Sprat 1722), and the Berlin Academy of Sciences (1700) have been places where "real," "uncorrupted," openly communicated knowledge and research (Sprat 1722) of an evidence-based theoretical style (i.e., Bacon-Leibniz-Descartes) were developed.

The role of the university was endangered by the tabula rasa thinking of the French Revolution (1789-1799), and most universities were closed (Rüegg 2004). Yet, secular interests (also) induced a profession-related profiling of universities. The history of the École Polytechnique in 1794 is an example; Napoleon made it a military academy in 1805 , and it is still assigned to the ministry of defense (B3). However, the objectives of the École Polytechnique's founders went beyond a professional engineering education to include the development of general technological knowledge (e.g., on chemical processes and electricity) so that governmental civil servants could better understand the first Industrial Revolution (B2) (Torstendahl 1993).

In Germany, Wilhelm von Humboldt (1767-1835) launched a new kind of university (Paletschek 2002) that inextricably linked teaching and research (B4) and viewed both as inseparable core responsibilities of professors (Teichler et al. 2013). Students became apprentice researchers, learning by assisting their professors' research. Founded in 1810, Berlin University became a free, independent institution that elected professors according to scientific criteria (Rüegg 2004). In Britain, Oxford and Cambridge "largely remained the domain of the very wealthy and the aristocracy, offering courses ..., which were of little use to the burgeoning steel and textile mills and the growing locomotive and civic infrastructure demands of the nineteenth century" (Boggs 2015, p. 51). Yet, many technical universities were founded in nineteenth-century commercial centers serving industry, finance, and stock exchanges (Klinge 2004), and many professors took leading positions in politics (B5).

American universities widely followed the Humboldtian model. At the end of the nineteenth century, US universities became research universities with disciplines and departments as places for education. As the hierarchical structure of the chair-based university was "unacceptable to democratic America" (Abbott 2005, p. 208) (C4), disciplinary departments were led by an elected leader. In a discussion of entrepreneurial and problem-oriented universities, the role of disciplines becomes disputed (C2). Yet, according to Abbot, disciplines (1) provide "academics with a general conception of intellectual existence" including career identities. He considers (2) disciplines as an economic means "preventing knowledge from becoming too abstract or overwhelming" (Abbott 2005, p. 210). Disciplines (3) organize the maintenance and production of scientific results in cohesive structures and realms. Abbot considers disciplines superior to problem-based organizations as (4) interdisciplinarity "has generally been problem-driven, and problems have their own (often short) life time" that "does not provide a good foundation for life-time training or career building" (Abbott 2005 , p. 218). Problem-bound knowledge is also (5) insufficiently abstract to be applied to other problems. We argue (6) that disciplines provide a means of complexity reduction. For instance, psychology, economics, or sociology may be viewed as tools that explain the (general and basic drivers) of individual, economic actors and (subsystems of) society (Merton 1938; Scholz 2011). Finally, (7), the university adapted to industry-like (mass) production (Clark 2008). At first in Protestant countries, scientific papers became a main criterion for appointing professors. 


\section{From the WWII university to the democratic mass university: Emerging interdisciplinarity}

War is a hostile, disruptive, usually nationalistic means for extending political, physical, territorial, or other forms of power. Thus, reflecting on the roles and functions of universities without considering them in times of war is incomplete. Several key features are illustrated by World War II. The Nazi takeover of universities began on November 11, 1933, with German academics making a commitment to Hitler (Nationalsozialistischer Lehrerbund 1933), signed finally by about 900 professors. When the Nazis took power, 213 philosophy teachers were at the professor level; of the 173 who did not emigrate, $45 \%$ joined the Nazi Party (Leaman 1993), demonstrating that destructive ideology can enter the social sciences. Psychology as a social science became professionalized in Germany under the Nazi regime (D2) (Geuter 2008). The political regime altered subjects and ways of conducting research (Leaman 1993, p. 108). In Germany, abstract Jewish nuclear physics was abandoned and replaced by Aryan physics, promoted by the German Nobel laureates Lenard (Lenard 1936) and Stark (Stark 1937). The Frankfurt School of Philosophy and Social Science closed, and the Vienna Circle disbanded; Jewish scientists were banished from universities. In addition, the Soviet universities' science was ideologized, and academic freedom curtailed. Lysenkoism, a theory of the agro-biologist Trofim Lysenko, denied Mendelian-Darwinian genetic mechanisms. Plants were viewed as environmentally adaptable, in line with Lamarckian theory (Aspiz 2007), leading Stalin to fire 3000 genetics-oriented biologists in 1948 (Birstein 2009).

In regard to the United States, we can cite the Manhattan Project as an example for a problem solving project (D3). Otto Hahn described the nuclear chain reaction in December 1938. Albert Einstein informed Franklin Roosevelt in a letter on August 2nd that the Germans were actively supporting research to produce "extremely powerful bombs ..." (Gosling 1999) using uranium. Presumably, and fortunately, no one in the Nazi government recognized this destructive potential as they refused abstract Jewish physics. After Roosevelt's discussion of Einstein's letter on October 11, 1939, three years passed until the Manhattan Project began in November 1942. The interdisciplinary project included physicists, chemists, and engineers from top-ranked universities (D1). Finally, "some 150,000 people were employed in the project" (Reed 2014) in a kind of knowledge workers' conception.

Warfare requires sophisticated strategic planning. Starting in 1940, nearly 1000 physicists, mathematicians, engineers, economists, and others who had mastered some mathematization were engaged in operations research in Britain's army. This required "inter- or cross-disciplinary" work, often promoted by the power of abstraction and mathematization providing a "a different feel of the world" (1993, p. 597) that helped the British crack the German U-boat code, for example (Waddington 1973). Given the success of applied science in WWII, Vannevar Bush's 1945 report (Busch 1945) to the US president paved the way for continuing high-level research at universities including an industrial-military-university alliance.

Interdisciplinarity comprises theories and methods that merge concepts and methods from different disciplines (Duguet 1972; Scholz et al. 2000a, b). Game theory, founded by economist Oskar Morgenstern and mathematician John von Neumann (1944), or operational research (Gass and Assad 2005; Morse and Kimball 1946) as genuine interdisciplinary fields rooted in military problem-solving and, thereby, interdisciplinarity developed in the aftermath of WWII. Historically, cybernetics "as the scientific study of control and communication in the animal and the machine" (Wiener 1948), and systems engineering, dating back to the foundation of Bell Telephone Laboratories in the early 1940s (Brill 1998), fall into this category. We should note that the methods used for coping with the complexity of sustainable transformations (Bergmann et al. 2013; Gregory et al. 2012; Rosenhead and Mingers 2001; Scholz and Tietje 2002) and the current complexity science (Helbing et al. 2015) and integrated modeling for global environmental change (Bouwman et al. 2006) are strongly rooted in these disciplines. A major contribution of cybernetics was the provision of a general, abstracted language to describe dynamics, interactions, and feedback control systems in and between systems that are subjects of different scientific disciplines.

After World War II, we were "witnessing the beginnings of a world science, transforming old and creating new industries, permeating every aspect of life" (Bernal 1954) (E). A rapidly growing science system was promoting unprecedented economic growth linked to exponential increases in energy and material consumption. Rachel Carson (1962) classic, Silent Spring (Carson 1962), and Kenneth Boulding's metaphor of Earth as a spaceship sharply raised awareness of the comprehensive cultural, social, and environmental crises (Altbach 1995) facing Western society.

The 1968 student movement happened more on the streets than in scientific papers and universities' lecture halls, while in many parts of the developed world, new universities emerged as the start of the "democratic mass university" (Zomer and Benneworth 2011) (F2). Universities were semiindependent, providing citizens and society with intellectual resources as a public good (Zomer and Benneworth 2011). 
The Center for Interdisciplinary Research at the University of Bielefeld was institutionalizing interdisciplinarity in 1969 but remained untouched from student riots topics (F1) (Schelsky 1967). We can read in the foreword of the 1970 OECD seminar "Interdisciplinarity: Problems of teaching and research in universities" (Apostel et al. 1972) that "the impact of knowledge on action - whether in the field of social or natural phenomena - forces interaction between the disciplines and even generates disciplines" (Gass 1972). A large number of new issues, methods, and research paradigms developed, as described by Thomas Kuhn (Kuhn 1962). The science community was facing a rapid increase in the numbers of journals, disciplines, and institutions. Yet, strategies for how to integrate this knowledge were missing. Recognizing that a unity of knowledge (Oppenheim and Putnam 1958) and of science (Wilson 1999; consilience) could not be achieved easily, interdisciplinarity developed as a second mode of doing science. Quite remarkably, like the OECD conference, this was done without (evident) relationship to the student movement.

At the 1970 OECD seminar, Jean Piaget (1972) challenged an inner science (Mode 1), epistemology-based knowledge integration (1972). In contrast, Erich Jantsch (Jantsch 1972) referred to the "purposive level" (G2) as a means whereby universities become "transdisciplinary" institutions, already envisioning a post-industrial society. Instead of working as a "laissez-faire type of selforganization" describing "what is," theories should focus on "what should be". Jantsch promoted knowledge (Bildung = education) for enabling the "judgment of complex dynamical changing situations" and "research on complex dynamic situations". The university should take "an active role in planning for society ... and technology in the service of society," and "Ultimately, the entire education/ innovation system may become coordinated as a multilevel multigoal hierarchical system through a transdisciplinary approach, implying generalized [presumably societal; RWS] axiomatics and mutual enhancement of disciplinary epistemology".

\section{In what ways do we face a bifurcation between transdisciplinarity and the commercialized university?}

The roles and functions of the university have changed with technological innovation and societal development. Some of the characteristics, such as organization in faculties (A2), governmental authorization (A3), disciplines as grids for knowledge organization (C2), and a world-science system
(E1), remained. Others, such as the Humboldtian unity of research and teaching (B4) and perhaps societal reputations (A4), were changed. The shift toward a mass university in the emerging knowledge society since about 1980 made the university a key institution where knowledge and society were interconnected. The next two sections outline two qualitatively different pathways, transdisciplinarity and (a) the commercialization of research (including the Triple Helix approach) and (b) the loss of freedom and independence needed in transdisciplinary processes. We then discuss mechanisms that may underlie these complementary developments.

\section{Transdisciplinarity as mutual learning processes between science and practice}

In the 1980s, a sequence of globally noted environmental disasters (Bhopal 1984; Chernobyl 1986; Schweizerhalle 1986); atmospheric physicists' warnings about the Earth system's ozone hole (Molina and Rowland 1974); and rising concerns about global pollution and warming (Broecker 1975) launched the foundations of environmental agencies and departments worldwide (G1). The necessity to understand and manage environmental degradation, damages, or risks and which (e.g., animal species) should be safeguarded promoted interdisciplinarity and transdisciplinarity. Thus, knowledge from the natural and engineering sciences and social sciences had to be merged. For instance, both risk assessment and risk perception were needed for risk management.

Switzerland has been a pioneer in transdisciplinarity. In 1991, the Swiss National Science Foundation (SNF) initiated the Swiss Environmental Priority Programme (SPPU). All of its projects were required to include transdisciplinary research. Examples are the requests for joint problem definitions of research objectives by science and practice and the valuation of research outcomes by mixed groups of scientists and practitioners (Häberli and Grossenbacher-Mansuy 1998, p. 206). Independent of the SNF program, since 1993, a comprehensive practice of transdisciplinary projects has developed at the Department of Environmental Systems Science of ETH Zurich. Transdisciplinarity processes were viewed as a basic means of sustainability learning (Scholz et al. 2006). The necessity of joint problem definition, representation, and transformation by mutual learning (Scholz 2000; Scholz et al. 2000a, b) and (method-based) knowledge integration from science and practice culminated in the ideal of science and practice co-leadership while retaining the full independence of science (as only sponsoring is considered). 


\section{Box 1: Principles of transdisciplinary processes}

The principles herein were developed over the course of more than 40 large-scale projects approaching transdisciplinarity. They are based on the Zurich 2000 conception of transdisciplinarity and are currently being applied in a societal learning process for developing socially robust solutions.

\section{Roles and independence}

Co-leadership To ensure joint problem definition and representation, co-designing of the study, co-creation of knowledge, and joint development of socially responsible solutions, practice must have incentives and the desire to participate in a tangible way.

Equal footing The equal appraisal of high-quality knowledge from practice and from science.

Accepting the otherness of the other. The roles, values, and interests of different stakeholder groups and disciplines are considered variable contributions for identifying socially robust solutions.

\section{Rules of mutuality}

Mutual learning as a basic principle Based on thorough reflection and reflexion on roles, interests, and knowledge of (disciplinary) science contributions and stakeholder knowledge and interests, mutual learning by science and practice is a basic principle of transdisciplinarity.

Facilitation of the process As presented in Fig. 1, a transdisciplinary process calls for initiating, relating, and integrating a targeted interdisciplinary process and a multistakeholder discourse. This, in turn, requires a method-driven process that may include both formative processes (such as joint scenario formation or modeling) and deliberative discourses.

\section{Constraints}

Precompetitive and no day-to-day politics To encourage open, creative, innovative thinking and switching from positions to interests (Fischer et al. 1981), competitive economic issues and topics related to ballot-box agendas are excluded. Thus, politicians (in contrast to civil agents) are usually excluded from direct participation but are affiliated in a monitoring role.

Sponsorship instead of contract-based research Science needs freedom to make cutting-edge knowledge available and to nurture and develop ideas that emerge from transdisciplinary discourses, e.g., groundbreaking ideas for sustainable transitioning. This cannot be achieved in a principal-agent relationship in which funders control what is done and what is published.

Extended Chatham house rule A transdisciplinary discourse calls for trust among participants and (non-penalized) outside-the-box thinking. Participants must be assured that no other members will cite or refer to preliminary ideas "which are generated in the learning process". Therefore, by signed agreement, members must demonstrate their willingness to adhere to these rules (which may be interpreted as by-laws and an extended Chatham House Rule).

\section{Outcomes}

Socially robust orientation Socially robust orientations (instead of long lists of policy recommendations) characterized by an if/thenlike reasoning (if you want to attain A, do not do B because ...) are a main outcome of a transdisciplinary process.

The five-year (externally induced) SNF SPPU program (a large program with about 60 mio CHF) and long-term learning for conducting transdisciplinary studies at ETH have shown different levels of success. Simplified, most SNF scientists were unfamiliar with transdisciplinarity and just included criteria formally in the proposal (Zscheischler and
Rogga 2015). There has been no strategy for involving stakeholders, and practitioners have been missing on the program board (Buser 1992). The balance of the ETH case studies (running since 1993) is more promising. Globally, about 50 large-scale transdisciplinary projects have followed this model (Scholz and Steiner 2015b). The ETH case studies have shown greater reservations with respect to a "straight problem-solving" aspiration than the SNF approach. The participating stakeholders' learning and the development of socially robust orientations (Gibbons and Nowotny 2001) have been in the foreground. In 2000, the heads of the NSF and the ETH case studies, together with representatives from industry (i.e., ABB) and civil organizations (e.g., the Swiss Foundation Science et Cité) launched the Zurich 2000 conference on Transdisciplinarity: Joint problem-solving among science, technology, and society: An effective way for managing complexity. This event, attended by 300 practitioners and 500 scientists, may be seen as the cradle of transdisciplinarity practice and theory (Häberli et al. 2000; Klein et al. 2001; Scholz et al. 2000a, b).

Factually, the use of the term "transdisciplinarity" has blurred in recent years. Transdisciplinarity's use of the term still ranges from "being very interdisciplinary" or "including stakeholders" (meaning participatory research) to postnormal science conceptions (Pereira and Funtowicz 2006) or Basarab Nicolescu's cosmodernity (Nicolescu 2014). The philosopher Mittelstrass considers transdisciplinarity "a principle of research and science ... which arises in cases concerning the solution of non-scientific problems" (Mittelstrass 2011) and thus reflects on how scientists relate their research to practice. Below, we go beyond such a view and focus on transdisciplinary approaches that include tangible stakeholder collaboration. Figure 1 presents what is understood as the process for the DiDaT (Digital Data as the subject of Transdisciplinary Processes) project for the responsible use of digital data. A transdisciplinary process includes (a) a targeted, interdisciplinary scientific process; (b) a (mitigated) process among representatives of key stakeholder groups; and (c) a linkage between these two, including the formation of science and practice co-leadership to allow for collaboration that includes joint problem definition and representation, the construction of socially robust orientations for problem transformation (solutions), and a thorough process of reflection to promote future sustainable action.

The author's experience initiating and/or participating in more than 25 large-scale transdisciplinary projects has identified the need for the thorough inclusion and co-leadership of practice (e.g., the Swiss nuclear industry's research on policy processes) in transdisciplinary processes that call for conceiving science as a public good (G2). This does not allow for third-mission-like, contract-based research (G3); only 


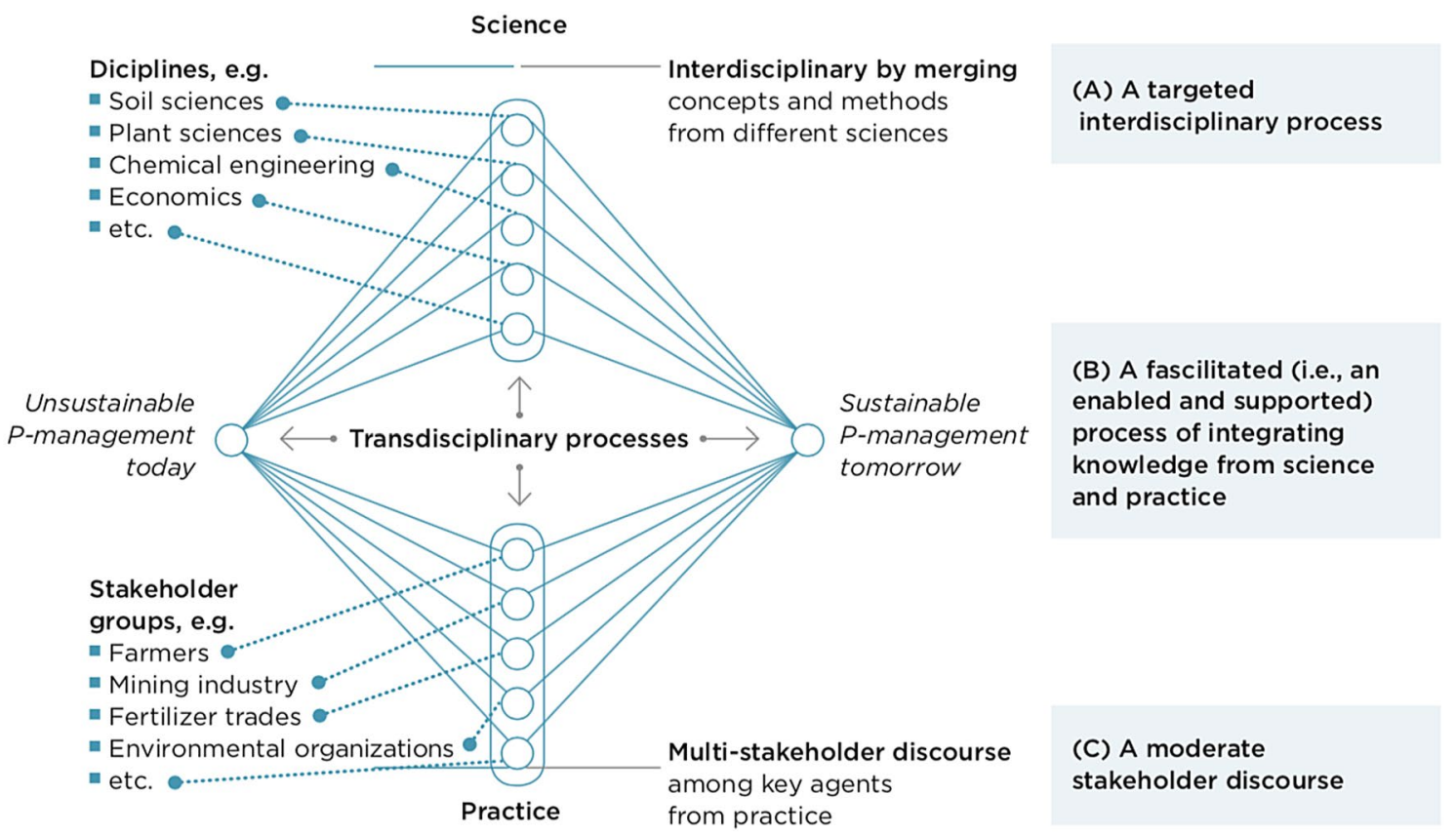

Fig. 1 The three components of a transdisciplinary process for the Global TraPs project ( adapted from Scholz and Steiner 2015a)

sponsorship allows research freedom (Shrestha et al. 2017) (A3). Co-leadership among science and practice must be a prerequisite for authentic involvement of practitioners (62).

Various transdisciplinary processes meet the ideal form of transdisciplinarity (see Box 1). Examples refer to studies on sustainable transitioning of urban mobility in Gothenburg (Loukopoulos and Scholz 2003; Scholz et al. 2003), traditional industries in rural areas of pre-Alpine Switzerland (Stauffacher et al. 2008), African smallholder farmers' fertilizer use (Arusey et al. 2018; Njoroge et al. 2015), and many other cases (Scholz and Steiner 2015b). We briefly present the example of a global transdisciplinary process on sustainable biogeochemical cycle management, the Global Transdisciplinary Process for Sustainable Phosphorus (Global TraPs) project. The idea for this study emerged from a 2007 science-practice workshop on mineral scarcity (Wolfensberger et al. 2008).

The identification of a democratically legitimized practitioner to serve as a co-leader for global phosphorus flows (such as the president of a canton for a regional study) has been challenging. As more than $85 \%$ of mineral phosphorus is used for fertilizer, the International Fertilizer Industry Association (IFA) can be considered a proper representative. Finally, in agreement with IFA, Amit Roy, now-retired head of the International Fertilizer Association (IFDC), and Roland Scholz (ETH Zurich) became the practice and science co-leaders, respectively. The guiding question was developed in a discussion among a wide range of stakeholders (including farmers' organizations and Greenpeace) and reads:
"What new knowledge, technologies and policy options are needed to ensure that future phosphorus use is sustainable, improves food security and environmental quality, and provides benefits for the poor?"

Stages of the supply chain including excavation, mining, processing, use, dissipation, and recycling, and overarching trade and finance issues were taken as a system model and foundation for building subgroups (facets). For each facet, co-leadership by a practitioner and scientist and the inclusion of representatives of relevant key stakeholder groups and science experts for critical aspects were launched to establish a balanced representation of science and practice at all levels. The key functions of a transdisciplinary process such as the Global TraPs project are capacity-building in science and practice, consensus-building (on what the key problem is), mitigation (as sustainable transitioning has losers and winners), and the (political) legitimization of decision-makers - one of the key issues of transdisciplinary processes. More than 200 representatives of science and stakeholder groups participated in the 2010-2013 process. The results (i.e., the socially robust orientations) were documented in a co-authored book by 51 participants (17 from practice, see Scholz et al. 2014), with chapters addressing socially robust orientations at different stages of the supply chain.

Global TraPs enabled a 5-year process of mutual learning for scientists and practitioners. The project received multiple sponsorships from industry, the UN, and common science funding. Contract-based research was declined to maintain independence with respect to funders' interests. Global TraPs may be viewed 
as a temporal institution (see Hukkinen et al. 2006). The UNEP Global Partnership on Nutrient Management (GPNM) Phosphate Platform was founded in December 2014 and planned as permanent follow-up institution that aspired to work in a transdisciplinary manner (Scholz et al. 2015).

We could learn from the Global TraPs project that also privately sponsored collaboration may well serve the public good if practitioners and scientists take co-responsibility, co-accountability and co-leadership on equal footing (see Box 1); keep the freedom and independence of research (A3) is a prerequisite of contributing to groundbreaking innovations of the digital transition. This is represented by the $y$ -axis of Fig. 2. We should note that independence of science and academic freedom are a basic right of the German constitution (see Bundesrepublik Deutschland 1949, pp., §5, art. 3 ) and other countries and us is also a subject of discussion in China (Qi 2017).

\section{Commercialization of universities: entrepreneurial universities and the third mission}

Parallel but independent from the genesis of universities' (transdisciplinary) sustainability research, scientific knowledge and education have become commercialized for various reasons. First, there has been increasing pressure from business, governments, and societal groups for universities to contribute to societal problem-solving. Society was facing a rapid increase in perceived uncertainty and complexity associated with technology development and globalization. Not coincidentally, chaos theory (Gleick 1987) and complex systems theory were viewed enthusiastically as world model by many. Innovation was considered an economic success factor and became a key policy means. As indicated by the term Mode 2, research became widely privately funded and "carried out in a context of application". As expressed by Peter Scott (Scott 2007), professors became knowledge workers (B2; also represented in the bottom-left quadrant of Fig. 2).

Second, universities with "unlimited expectations and limited resources" were facing funding crises in the 1980s (Zomer and Benneworth 2011). In striving for economic well-being, policy makers and university actors were pushing toward "consultancy", planning to "aggressively commercialize their findings" (Zomer and Benneworth 2011), and facilitating the use of research findings by industry. Funding became widely privatized. A comparative study including six European countries showed that public funding decreased from about 50\% in 1970 to below $20 \%$ in 2002 (Lepori et al. 2007).

Third, governments also developed strategies for including universities in their political programs. Thus, the social and planning sciences "were facing a shift of funding toward policy programs" (Zomer and Benneworth 2011). Funding was provided for developing and participating in urban or regional development processes instead of for conducting basic research to understand the roots of social problems. Here, a linkage to sustainability research was also established in some places (Driessen 2015). There was an urgency toward usefulness, and societal relevance (often interpreted as political or economic impacts) became a key criterion of funding (in the Netherlands and the EU). Many new departments, curricula, institutions, and universities (open or completely externally privately funded) were constructed to serve market needs (this is expressed by the arrow " 2 " of Fig. 2; much of the public services in the lower right quadrant can be bought from private companies).

The entrepreneurial university was born and the term "third mission" coined. The elite university and the 1970s' type of university providing education and research for the public good became commercialized, and the number of universities increased.

The "multidirectional interaction of overlapping roles" that culminated in the concept of the Triple Helix, which stresses "university-industry-government relations" (Etzkowitz and Leydesdorff 1998) for "knowledge-based economic development" (Etzkowitz and Leydesdorff 1995) took on an economic and Mode 2 perspective, perhaps most pronounced in the case of The Netherlands. In a critical, focused description, this may be considered an elite model in which-in conflict with the idea of science as a public good-professors underwent a "chameleon-like change of role functions ("changing hats')" (Scholz 2017) from teachers to politicians and industry leaders. These new "university-industry-government relations" were conceptualized

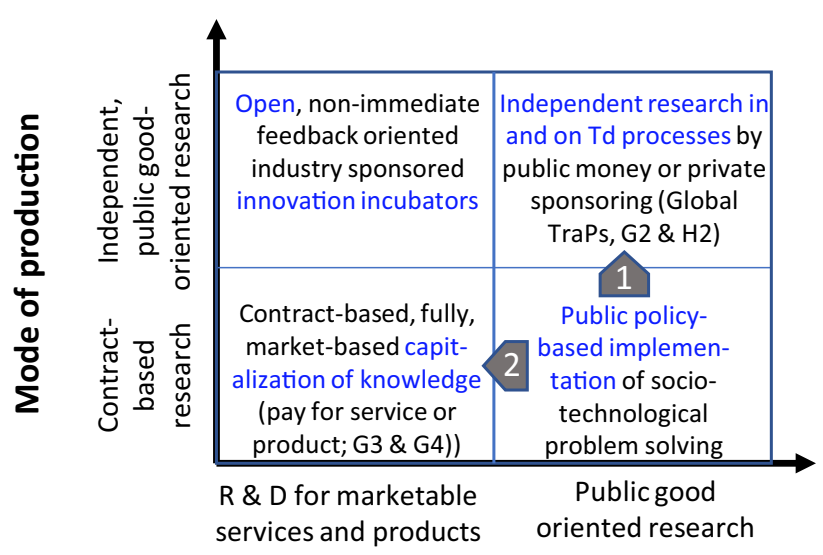

Type of product

Fig. 2 The mode of production $\times$ type of product table. Arrow 1 indicates that (much) contract-based research may support authentic transdisciplinary processes. Arrow 2 indicates that what is labelled "public-good-oriented research" often funding can also be conducted by private research/consulting institutes (as it represents a specific type of research). G2 to $\mathrm{G} 4$ and $\mathrm{H} 2$ refer to functions of universities in Table 1 
by the Triple Helix concept (Leydesdorff and Etzkowitz 1996), which has not been related to ideas of sustainability but rather to staying competitive and providing wellbeing through (technological) innovations. The relationship between universities and practice changed.

This view of university serving the market by contractbased, fully market-related capitalization of knowledge (bottom left quadrant of Fig. 2) is in conflict with the university as a public good which is-with two-thirds of the students enrolled in public universities (Levy 2018) —widely paid by the taxpayers. This would ask universities (a) to serve all stakeholder groups (working within the framework of a national constitution and human rights) to better cope with fundamental challenging societal problems (right column of Fig. 2). A special role and function of the university (b) is to preserve (living) intellectual heritage, for instance according to Piaget (1968) conception of genetic epistemology. Piaget elaborated that ontogenetic and phylogenetic development of knowledge are related and that the formation of individual's and societal operational thought and cognitive capacities are related access to the institutionalized preservation and codification of evolutionary and historically acquired knowledge.

\section{Discussion: the university at multiple crossroads}

The historical analysis provides the following picture: In the shift toward a digitalized, highly differentiated knowledge society, the university has become a very heterogeneous, multifaceted institution. The wide range of universities share the organizational model of the Bologna University (A1-A6), and they deal with cultural and human materials in universalistic terms" (Ramirez et al. 2016), yet they are extremely diversified regarding objectives, profiles, and quality. Colleges and universities range from several elite institutions where most of the historical features of Bologna, Humboldtian, and the disciplinary university remain visible (see Table 1) to a still-rapidly increasing number of applied or regional teaching-oriented knowledge institutions serving professional or specific occupational education. Universities are at a multiple crossroads with paths to different forms of doing science for and with society.

\section{Tensions between third mission and transdisciplinary practice}

With the shift toward the knowledge society late in the 1980s, Mode 2 research, the third mission of universities that first focused support on national and regional industries, and a Triple Helix-like view on how universities may serve governmental and business interests developed. Together with reductions in public funding, a widely spread request towards privatization of research and education took place (Verger 2016). This led to a departure from the ivory tower and to a global valorization of universities from a business and industry perspective. Later the idea that universities may help in solving social problems or assisting in implementing governmental programs emerged as a second variant of the third mission. Concurrently, government funding in many countries (particularly in Europe), tending to overemphasize direct social problem-solving, launched contract-based types, e.g., of research for environmental contamination and, some years later, for supporting governmental policy projects. Thus, professors tended to become knowledge workers, and many scientists became tools for politicians, helping to solve social problems inadequately addressed by governmental agencies.

The practice of transdisciplinarity at the time of the Rio summit emerged from the stance that Earth is in a highly vulnerable state, and research on how to enable resilient coupled human-environment systems is sorely needed. The systemic complexity and the diverging societal interests linked to environmental issues call for transdisciplinary processes that link academic rigor with experiential wisdom (particularly contextualized knowledge) when accepting the otherness of the other (particularly societal values in their cultural settings). Therefore, science with society must supplement science for society as suggested by transdisciplinarity (see Fig. 1, Box 1). Against this background, successful transdisciplinarity practices have developed independent of the third mission (in Europe, Japan, South Africa, and elsewhere).

Transdisciplinary processes provide strategic sustainability management in a precompetitive stage of development. This cannot be attained by contract-based research. The participation and inclusion of practitioners as co-leaders costs time and, thus, money. Yet, stakeholder groups participate (and invest in the process) only if they see incentives and benefits. Payment is provided by gaining new knowledge and something they would not get without participating in transdisciplinary processes (e.g., building new networks, generating new knowledge, anticipating conflicts or benefiting from the potential to adapt to societal need and users' preferences). Transdisciplinary processes and transdisciplinary research partnerships (Dedeurwaerdere 2014) can address relevant, complex issues that science and single stakeholder groups cannot address for various reasons (including the need for joint problem definitions and missing knowledge).

The dimensions of the type of product $\times$ mode of production table (Fig. 1) represent two crossroads universities are facing. The type of production juncture refers to how much directly market-related research for marketable services and products and development a university promotes and how much effort is expended to serve the public good. The Mode of production juncture refers to the extent to which a university's research is dependent on constrained, contract-based 
research or the extent to which it may follow research agendas that are (widely) independently defined. If we consider the challenge of developing groundbreaking sociotechnological, sustainable innovations as part of university research and acknowledge that the complexity of real-world problems in the shift to the post-industrial age calls for the inclusion of the epistemics of practitioners, then collaboration with practice is necessary and participatory or transdisciplinary research must be included. The upper quadrants of Fig. 2 represent this; the top-right section includes public-goodoriented transdisciplinary processes and targeted interdisciplinary research (see Fig. 1). Thus, the author of this project has colead/participated in numerous projects (Scholz and Steiner 2015b) where industry not only provided funding by sponsoring research but also participated in the process without directing scientists' activities in regard to the identification of goals. The upper-left section relates to external private funding for domains that produce market-relevant knowledge. There is a long tradition of this. In the early decades of the Industrial Revolution, industries financed local universities' chairs of chemistry, as they saw a need to have qualified future personnel available, and they hoped to benefit from research conducted at these institutes and new inventions provided by them. Today, we also find funding for institutes that are developing premarket technologies from which (local) industries may benefit.

We may hypothesize that only a few top-ranked universities in wealthy democratic countries can afford to follow what we may call an independent research variant. We posit that only this variant allows the university to function as a (mostly unbiased) clearinghouse for science and for professors to function as honest knowledge brokers (Pielke 2007). Currently, there is a strong trend towards the capitalization of knowledge practice, although many universities may pursue different roads in various departments or projects. Top universities in wealthy countries may have (sufficient) financial and academic freedom to maintain an independent research variant. For example, ETH's new president, Joël Mesot, noted that strong "basic public funding" is a "trump" of Swiss universities as called for by "long-term and highrisk projects" (Furger and Donzé 2019). He further argues that maintaining this stance does not allow for more that $25-30 \%$ third-party funding. We argue that this a fortiori holds true for high-profile transdisciplinary processes.

We may also question whether we should strive toward transdisciplinary business entrepreneurship. Clearly, transdisciplinarity may be professionalized; professional education to become a facilitator is possible. Thus, there is certainly an option for facilitators to earn money by contributing to successfully facilitating sustainable transitions. But maintaining independence is the prerequisite for facilitators to work as honest knowledge brokers (Pielke 2007). In the Global TraPs project, the fertilizer industry provided sponsorship. The interest was to identify the most critical pitfalls of unsustainable phosphorus in order to avoid unwanted (economic and political) rebounds of corporate activities. As the objective guiding question of "benefits for the poor" indicates, there has also been (some common) social entrepreneurship (Scholz 1994). But can the entrepreneurial vision be applied to science? The idea that science should be for a private good (Samuelson 1947) is in sharp contrast to the principle that transdisciplinary processes address open, ill-defined sustainable transitions that should benefit society and avoid any unwarranted losers. For this reason, sponsorship rather than contract-based research is needed. What is contributed or designed by science should be defined based on (long-term) sustainability and not from a current market perspective.

\section{Mechanisms promoting third-mission entrepreneurial university activities and transdisciplinarity}

We present two ideas to shed some light on the mechanisms underlying the emergence of the commercialized thirdmission-oriented and on the transdisciplinary processes at sustainability-oriented university.

The shift of the university to an entrepreneurial, commercialized institution is an impact of the usability of scientific knowledge by industry and business. Firms are compelled to acquire access to university knowledge. "The "capitalization of knowledge' is at the heart of the entrepreneurial academic mission, linking universities to users of knowledge more tightly and establishing the university as an economic actor in its own right" (Etzkowitz 2017). We have discussed the impact of ideologies on the science system. The Etzkowitz quote works well to pinpoint the mechanism by which free market rules also rule universities. Naturally, the objective of serving (non-commercial) societal demands also emerges in various conceptions of the third mission. But, given the gravity of the capitalization trend, this may be conceived as secondary.

When looking at the dichotomy between freedom vs. responsibility, transdisciplinarity and sustainability stress the latter. A key view underlying this paper is that universities and/or societies must take responsibility for the viability of future generations. Whether humans will promote lifethreatening settings in the distant future (e.g., by extreme climate change or a lack of access to mineral phosphorus) is not of interest from the perspective of free-market actors (who have to survive on the market) but is a matter of taking long-term responsibility for serving the public good. The time frame (including several thousands of years) and the level of abstraction (Jaques et al. 1978) are completely different from what rules capitalized knowledge. Thus, transdisciplinarity, as a methodology for producing groundbreaking 
sociotechnological innovation for resilient and sustainable human development, calls for the same level of research freedom as groundbreaking basic research. Further, sound and reliable basic research is needed for sustainability science if we postulate that groundbreaking sustainable innovations have to be based on "disciplined (discipline-based) interdisciplinarity in transdisciplinary discourses" (Scholz 2011). In this context, the academic disciplines (C1-C3) will be needed to maintain the clearinghouse functions of science (Scholz 2011). This does not only refer to traditional disciplines such as physics or economics. Also new disciplines are important. For instance, industrial ecology embodies theories and methods (Suh 2008) which allow for a validation of statements on environmental systems. Disciplines preserve and develop sound, properly validated, and (it is hoped) fraud-resistant scientific knowledge on how abiotic and biotic processes (including the rationale drivers of social/human systems) work.

Governing for the public good is not a matter of volatile markets but one of long-term and sustainable public governance that properly considers the role of the university as a key institution for making higher knowledge available. Piaget's theory of Genetic Epistemology (Piaget 1968) may help to properly frame the university of the future. Piaget stated that the acquisition of higher-ordered knowledge (which goes beyond mental operations on what is directly perceivable) calls for institutions that codify, restructure, condense, and teach the relevant knowledge thus far acquired in human history in order to have efficient access. This can be guaranteed only by public institutions such as universities. This aligns with the economist Stiglitz's conclusion that "knowledge is complementary to private and public capital .... The efficient production and equitable use of global knowledge require collective action". In light of the increasing privatization of knowledge by private digital infrastructure providers, we may state that the "challenge facing the international community is whether we can make our current system of voluntary, cooperative governance work in the collective interests of all" (Stiglitz 1999).

Clearly, the answer to the question of which path to choose between a properly framed commercialization of university services and providing grounds for a publicgood-oriented, freedom-of-research-based university is not an "either/or" response. In principle, the management of any university today is facing the situation of finding a smart allocation among multiple functions and services.

The commercialization has also an educational side. This includes the question of what types of bachelor, master, and $\mathrm{Ph} . \mathrm{D}$. theses are offered. Currently, we are facing a range from disciplinary basic research via inner science or applied interdisciplinary research to problem-solving and technology development-oriented theses where students are placed in a company. The same holds true for teaching, which can range from frontal lecture-based instruction to the projectbased training of skills or research. The classical range between basic and applied research has been extended. On the one hand, "universities are facing pressure to maximize social return and public investment in research to enhance universities self-sustenance" (Markman et al. 2008). The idea to conceive of universities as smart, capitalized, innovative, problem-solving providers, as suggested by Etzkowitz (2017), is portraying the end of one turn at the crossroads. At the end of the opposite road we may find the idea to declare the university a private good and research as well as (higher) education as a social technology and (critical) infrastructure of society.

If we take a look from the commercial side of the thirdmission perspective, we are facing a broad scope of forms and modes of cooperation regarding how universities work for and with industry. These range from contract research and consultancy to technology-transfer offices, science shops usually hosted by universities via science parks, open innovation incubators, and industry-university research parks via large-scale research corporations, such as the Semiconductor Research Corporation founded in 1982 (SRC 2019), which is the world's premier international, university-based research consortium with member companies and research programs spanning the globe. This consortium also funded the Japanese SEMATECH consortium and "SEMATECH Centers of Excellence in top US universities" (Browning et al. 1995, p. 127). However, this was "without regard for immediate and specific feedback" (Browning et al. p. 115), which would place this venture in the upper-left quadrant of Fig. 2. And the list ends with spin-offs that are independent private companies (that may use university's infrastructure under special conditions).

Looking from the societal side, research for society is usually promoted by special research programs or funding ranging in topics and scopes. Here we find contract-based consultancy, problem-oriented applied research initiated by local, state, country, or international institutions (e.g., the $\mathrm{UN}$ ) or supranational (e.g., the EU) governments. But there are also triple-helix-like projects such as the Dutch Knowledge for Climate (2007-2014) program that targeted knowledge transfer-based problem-oriented research "to develop applied knowledge through cooperation between the Dutch government, the business community, and scientific research institutes" (KfC 2019, see Fig. 1, bottom right)). Here we find mutual learning, co-leadership-based (see Box 1) transdisciplinary processes at the end turnoff from science to science with society. Though most of the processes have been on a local scale, there are transdisciplinary processes on national, international (Schori et al. 2009), and global scales (Scholz et al. 2014) on challenging issues such as nuclear waste. These processes allow for groundbreaking sociotechnological innovation for sustainable development. 
Yet this calls for financial independence (i.e., public funding or sponsoring instead of contract-based research), academic freedom, and a thorough public-good mission. Groundbreaking transdisciplinary processes, thus, very much resemble basic research and may be viewed as basic applied research with society on societally relevant transitions (Fig. 1, upper right). Thus, the way we conceive transdisciplinarity, transdisciplinary research is fully part of the research mission of the university.

\section{Conclusions}

Universities and science are at a crossroads and have to decide what share of their science staff will walk which pathway. There are two extreme turnoffs. One emphasizes commercialization and-in its extreme-conceiving of universities and scientific knowledge as a capitalized unit and private good subject of the neoclassical ideal of free market competition. This trend is much in line with further functionalizing university research for present-day, pressing social-political problems and programs of our seemingly fragile world. The other conceives of higher education and scientific research as a basic societal infrastructure and public good. Yet the history of science and the university has taught us that the production of knowledge needs proper institutional structures such as disciplines that function efficiently as clearinghouses of knowledge (with respect to consistency and empirical validation), engines for condensing knowledge to make it efficiently and reliably accessible, and to produce fundamental, grand theories for natural, social, and technological systems. In the emerging knowledge and (digital) information age, groundbreaking basic scientific knowledge cannot be produced on command and does not result from short-term, contract-based research. This holds true both for basic curiosity driven and transdisciplinary research. The continuous, robust, reliable access of science is a basic societal infrastructure and common good of the forthcoming knowledge and information age. The rationale or even ideology of a free capitalized knowledge market system as a ground layer of science development may be considered as a dysfunctional (short-term free market) ideology-driven distortion of science development. In principle, this approach ignores the rationale of science development as has been the case with the examples of the Soviet socialism worldview that abandoned Mendelian genetic approaches to evolution or the reasoning toward Aryan physics, which has to follow principles of simple order and understandability.

The tensions between the different lines are caused by the social drivers linked to them. The commercialization-capitalization view currently closely follows public (politics and tax-payer logic-based) justification pressure, which claims that universities should repay public investments to society by successfully operating as (knowledge) market actors. This is following short-term rationales, lacking the insight into the value and function of resilient, long-term, phylogenetic knowledge and science development. This is in strong contrast to the conception of the university as a public good. The university is not a company whose main purpose is to efficiently produce products for the market or to support governmental political programs.

Yet transdisciplinarity has opened a new chapter in funding competition between the basic and the applied science story. The presented version of transdisciplinarity suggests doing science with society in order to develop groundbreaking sociotechnological innovations and orientations for sustainability, which is a globally ratified regulating idea. Generating such groundbreaking ideas calls for disciplinebased, interdisciplinary research, which is a key element of transdisciplinary processes (see Fig. 1). Such processes should not be capitalized and follow short-term, marketbased funding rationales or short-term funding. They need proper (institutional) discourse arenas or transdisciplinary research institutions - perhaps of a period of 10 years- to properly utilize the power of targeted interdisciplinary processes and to include reflected, socially responsible practitioners. The idea to introduce such institutions has already been suggested at the Zürich 2000 transdisciplinarity conference under the label "Transdisciplinarity Colleges" (Scholz and Marks 2001). But there are only a few places (in Austria, Germany, Switzerland, and South Africa) where transdisciplinarity has been institutionalized thus far or research funding explicitly supports transdisciplinary processs such as the German FONA (Newig et al. 2019) or the Swedish Mistra (Polk 2014) program. Transdisciplinarity is not only a means of providing third mission-oriented services but-if we look at groundbreaking innovations-a key part of the research mission of the university. Therefore, we conclude that both sustainability science (with respect to transdisciplinarity) and universities call for proper institutionalizations that include adequate funding mechanisms for the range of services science is providing for and with society. This is an issue that has not yet been well deliberated.

Acknowledgements Open access funding provided by Danube University Krems University for Continuing Education. Thanks to Tom Dedeurwaerdere, Harald A. Mieg, Ortwin Renn, Uwe Schneidewind, Gerald Steiner, Olaf Weber, Friedrich-Wilhelm Wellmer, Sander van der Leeuw, Masaru Yarime and Verena van Zyl-Bulitta for their valuable input and Elaine Ambrose for the English-language editing.

Open Access This article is licensed under a Creative Commons Attribution 4.0 International License, which permits use, sharing, adaptation, distribution and reproduction in any medium or format, as long as you give appropriate credit to the original author(s) and the source, provide a link to the Creative Commons licence, and indicate if changes 
were made. The images or other third party material in this article are included in the article's Creative Commons licence, unless indicated otherwise in a credit line to the material. If material is not included in the article's Creative Commons licence and your intended use is not permitted by statutory regulation or exceeds the permitted use, you will need to obtain permission directly from the copyright holder. To view a copy of this licence, visit http://creativecommons.org/licenses/by/4.0/.

\section{References}

Abbott A (2005) Linked ecologies: States and universities as environments for professions. Sociol Theory 23(3):245-274. https://doi. org/10.1111/j.0735-2751.2005.00253.x

Altbach PG (1995) Problems and possibilities: The US academic profession. Stud High Educ 20(1):27-44

Apostel L, Berger G, Briggs A, Michaud G (1972) Interdisciplinarity: problems of teaching and research in universities. OECD, Centre for Research and Innovation, Nice

Arusey C, Nekesa AO, Ngetich WRN, Scholz RW, Kipruto KJ (2018) Efforts Toward Improving Maize Yields on Smallholder Farms in Uasin Gishu County, Kenya, through Site-specific, Soil-testing-based Fertiliser Recommendations: A Transdisciplinary Approach. East Afr Agric Forestry. https://doi. org/10.1080/00128325.2018.1443413

Aspiz ME (2007) To the 85th anniversary of Roman B. Khesin-Lurie. Russ J Dev Biol 38(5):332-334

Bakhshi H, Frey CB, Osborne M (2015) Creativity vs. robots: the creative economy and the future of employment. London: Nesta

Bergmann M, Jahn T, Knobloch T, Krohn W, Pohl C (2013) Methods for transdisciplinary research: a primer for practice. Campus, Munich

Bernal, J. D. (1954). Preface: Faber \& Faber.

Birstein VJ (2009) The perversion of knowledge: the true story of Soviet science. Hachette, Cambridge, M.A.

Boggs AM (1850s) Changing concepts of 'The University' and Oxford's governance debates, 1850s-2000s. Sciences in the Universities of Europe, Nineteenth and Twentieth Centuries. Springer, Dordrecht, pp 49-68

Bouwman AF, Kram T, Klein Goldewijk K (2006) Integrated modelling of global environmental change. Overv IMAGE 2(4):225-228

Brill JH (1998) Systems engineering - a retrospective view. Syst Eng J Int Counc Syst Eng 1(4):258-266

Broecker WS (1975) Climatic change-are we on brink of a pronounced global warming. Science 189(4201):460-463. https:// doi.org/10.1126/science.189.4201.460

Browning LD, Beyer JM, Shetler JC (1995) Building cooperation in a competitive industry-SEMATECH and the semiconductor industry. Acad Manag J 38(1):113-151. https://doi. org/10.2307/256730

Bundesrepublik Deutschland (1949) Grundgesetz für die Bundesrepublik Deutschland (1949)

Busch V (1945) Science, the endless frontier. A report to the President by Vannevar Bush, Director of the Office of Scientific Research and Development. Washington, DC: U.S. GPO

Buser H (1992) "Schwerpunktprogramm Umwelt" des Schweizerischen Nationalfonds ohne Beteiligung von praxisorientierten Ökologen? Gaia Ecol Perspect Sci Soc 1(3):181-182

Carson R (1962) Silent spring. Houghton Mifflin, Boston, MA

Clark WE (2008) Academic charisma and the origins of the research university. University of Chicago Press, Chicago

Dedeurwaerdere T (2014) Sustainability science for strong sustainability. Edward Elgar, Cheltenham

Dorling D (2015) Injustice (revised edition): Why social inequality still persists. Policy Press, Bristol
Driessen PPJ, Vellinga P, van Deelen CL, Slegers MFW, Döpp S, Heinen M, de Pater F, Piek O, van Nieuwaal K (2015) Knowledge for Climate: 2008-2014. Foundation Knowledge for Climate, Utrecht

Duguet P (1972) Approach to the problem. In: Apostel L, Berger G, Briggs A, Michaud G (eds) Interdisciplinarity: Problems of teaching and research in universities. OECD, Centre for Research and Innovation, Nice, pp 11-19

Etzkowitz H (2017) Innovation Lodestar: The entrepreneurial university in a stellar knowledge firmament. Technol Forecast Soc Chang 123:122-129

Etzkowitz H, Leydesdorff L (1995) The triple Helix-Universityindustry-government relations: a laboratory for knowledge based economic development. EASST Rev 14(1):14-191

Etzkowitz H, Leydesdorff L (1998) The endless transition: a "triple helix" of university-industry-government relations. Minerva 36(3):203-208

Etzkowitz H, Webster A, Gebhardt C, Terra BRC (2000) The future of the university and the university of the future: evolution of ivory tower to entrepreneurial paradigm. Res Policy 29(2):313-330. https://doi.org/10.1016/s0048-7333(99)00069 $-4$

Fischer R, Ury W, Patton B (1981) Getting to yes. Houghton Mifflin, Boston

Fortun M, Schweber SS (1993) Scientists and the legacy of World War II: the case of operations research (OR). Soc Stud Sci 23(4):595-642

Furger M, Donzé R (2019) Die Qualität der Maturanden ist sehr hoch. NZZ am Sonntag, pp 20-21

Gass JR (1972) Preface. In: Apostel L, Berger G, Briggs A, Michaud $\mathrm{G}$ (eds) Interdisciplinarity: Problems of teaching and research in universities. OECD, Centre for Research and Innovation, Nice, pp 10-11

Gass SI, Assad AA (2005) An annotated timeline of operations research: an informal history, vol 75. Kluwer, New York, NY

Geuter U (2008) The professionalization of psychology in Nazi Germany. Cambridge University Press, Cambridge

Gibbons M, Nowotny H (2001) The potential of transdisciplinarity. In: Klein JT, Grossenbacher-Mansuy W, Häberli R, Bill A, Scholz RW, Welti M (eds) Transdisciplinarity: Joint problem solving among science, technology, and society. An effective way for managing complexity, Birkhäuser, Basel, pp 67-80

Gleick J (1987) Chaos: Making a new science. Penguin Books, New York, NY

Gosling FG (1999) The Manhattan Project: making the atomic bomb. Unuted State Department of Energy, Washington, DC

Gregory R, Failing L, Harstone M, McDaniels T, Ohlson D (2012) Structured decision making. A practical guide to environmental management choices. Wiley, Chicester

Gulbrandsen M, Slipersaeter S (2007) The third mission and the entrepreneurial university model. In: Bonaccorsi A, Daraio C (eds) Universities and strategic knowledge creation. Specialization and performance in Europe, Cheltenham, pp 112-143

Häberli R, Bill A, Grossenbacher-Mansuy W, Thompson Klein J, Scholz RW, Welti M (2001) Synthesis. In: Klein T, Grossenbacher-Mansuy W, Häberli R, Bill A, Scholz RW, Welti M (eds) Transdisciplinarity: Joint problem solving among science, technology, and society. An effective way for managing complexity, Birkhäuser, Basel, pp 6-22

Häberli R, Grossenbacher-Mansuy W (1998) Transdisziplinarität zwischen Förderung und Überforderung. Erkenntnisse aus dem SPP Umwelt GAIA 7:196-213

Häberli R, Scholz RW, Bill A, Welti M (2000) Transdisciplinarity: joint problem-solving among science, technology and society. Workbook I: dialogue sessions and idea market, vol 1. Haffmans Sachbuch, Zürich 
Helbing D, Brockmann D, Chadefaux T, Donnay K, Blanke U, Woolley-Meza $\mathrm{O}$ et al (2015) Saving human lives: what complexity science and information systems can contribute. J Stat Phys 158(3):735-781

Hilbert M (2014) Technological information inequality as an incessantly moving target: the redistribution of information and communication capacities between 1986 and 2010. J Assoc Inf Sci Technol 65(4):821-835

Hukkinen J (2006) Institutions in environmental management: constructing mental models and sustainability. Routledge, London

Jantsch E (1972) Towards interdisciplinarity and transdisciplinarity in education and innovation. In: Apostel L, Berger G, Briggs A, Michaud G (eds) Interdisciplinarity: Problems of teaching and research in universities. University of Nice, Nice, pp 97-121

Jaques E, Gibson RO, Isaac DJ (eds) (1978) Levels of abstraction in logic and human action: a theory of discontinuity in the structure of mathematical logic, psychological behaviour, and social organisation. Heinemann, London

Kant I (1778/1779) The conflict of the faculties (M. J. Gregor, translation). Albaris, New York

Kant I (1784/1845) Verantwortung der Frage: was ist Aufklärung. Wörtlicher Abdruck. Stuhr'sche Buchhandlung, Potsdam

Kant I (1787/1965) Critique of pure reason (W. S. Pluhar, Trans.). Hackett Publishing Company, Indianapolis

Kant I (1979/1798) The conflict of the faculties, German: Der Streit der Fakultäten (transl. by M. R. Gregor). Abraris Books, New York

Klein J (2016) Francis Bacon. In: Zalta EN (ed) The Stanford Encyclopedia of Philosophy (Winter 2016 Edition). Stanford University, Stanford

Klein JT (2004) Prospects for transdisciplinarity. Futures 36:515-526

Klein JT, Grossenbacher-Mansuy W, Häberli R, Bill A, Scholz RW, Welti M (eds) (2001) Transdisciplinarity: joint problem solving among science, technology, and society. An effective way for managing complexity. Birkhäuser, Basel

Klinge M (2004) Die Universitätslehrer. In: Rüegg W (ed) Geschichte der Universität in Europa Vom 19. Jahrhundert bis zu zweiten Weltkrieg, vol III. C. H. Beck, München, pp 113-144

Krausmann F, Wiedenhofer D, Lauk C, Haas W, Tanikawa H, Fishman $\mathrm{T}$ et al (2017) Global socioeconomic material stocks rise 23-fold over the 20th century and require half of annual resource use. Proc Natl Acad Sci USA 114(8):1880-1885. https://doi. org/10.1073/pnas.1613773114

Kuhn TS (1962) The structure of scientific revolutions (two volumes), 3rd edn. Chicago University Press, Chicago, IL

Laredo P (2007) Revisiting the third mission of universities: toward a renewed categorization of university activities? High Educ Policy 20(4):441-456

Laws D, Scholz RW, Shiroyama H, Susskind LE, Suzuki T, Weber O (2004) Expert views on sustainability and technology implementation. Int J Sustain Dev World Ecol 11(3):247-261

Leaman G (1993) Heidegger im Kontext: Gesamtüberblick zum NSEngagement der Universitätsphilosophen. Argument-Verlag, Hamburg

Lenard P (1936) Deutsche Physik, vol 1. Lehmann, München

Lepori B, Van den Besselaar P, Dinges M, Potì B, Reale E, Slipersæter $S$ et al (2007) Comparing the evolution of national research policies: what patterns of change? Sci Public Policy 34(6):372-388

Levy DC (2018) Global private higher education: an empirical profile of its size and geographical shape. High Educ 76(4):701-715

Leydesdorff L, Etzkowitz H (1996) Emergence of a triple helix of university-industry-government relations. Sci Public Policy 23(5):279-286

Loukopoulos P, Scholz RW (2003) Sustainable future urban mobility: using 'area development negotiations' for scenario assessment and participatory strategic planning. Environ Plann A 36(12):2203-2226
Markman GD, Siegel DS, Wright M (2008) Research and technology commercialization. J Manage Stud 45(8):1401-1423

Merton RK (1938) Science, technology and society in the seventeenth century England. Osiris 4:360-632

Minshall T, Druilhe C, Probert D (2004) The evolution of 'Third Mission'activities at the University of Cambridge: balancing strategic and operational considerations. In: Paper presented at the 12th high tech small firms conference. University of Twente, Amsterdam (May 24-25, 2004)

Mittelstrass J (2011) On transdisciplinarity. Trames 15(4):329-338

Molina MJ, Rowland FS (1974) Stratospheric sink for chlorofluoromethanes: chlorine atom-catalysed destruction of ozone. Nature 249(5460):810

Montague HP (2013) The historic function of the university. In: World Yearbook of Education 1971/2 (pp. 27-38): Routledge.

Morse PM, Kimball GE (1946) Methods of operations research. Center for Naval Analyses - Operations Evaluation Group, Alexandria, V.A.

Nationalsozialistischer Lehrerbund (1933) Mit Adolf Hitler für des deutschen Volkes Ehre, Freiheit und Recht! Bekenntnis der Professoren an den deutschen Universitäten und Hochschulen zu Adolf Hitler und dem nationalsozialistischen Staat. Dresden: Nationalsozialistischer Lehrerbund

UN (United Nations) (1987) Our common future. Report of the World Commission on Environment and Development. Transmitted to the General Assembly as an Annex to document A/42/427Development and International Co-operation: environment. New York, N.Y.: Committee on Education of the Conference of NGOs from United Nations

Newig J, Jahn S, Lang DJ, Kahle J, Bergmann M (2019) Linking modes of research to their scientific and societal outcomes. Evidence from 81 sustainability-oriented research projects. Environ Sci Policy 101:147-155

Nicolescu B (2014) From modernity to cosmodernity. Science, culture, and spirituality. State University of New York Press, New York

Njoroge R, Birech R, Arusey C, Korir M, Mutisya M, Scholz RW (2015) Transdisciplinary processes of developing, applying, and evaluating a method for improving smallholder farmers' access to (phosphorus) fertilizers: the SMAP method. Sustain Sci 10(4):601-619. https://doi.org/10.1007/s11625-015-0333-5

Oppenheim P, Putnam H (1958) Unity of science as a working hypothesis. Minnesota Studies in the Philosophy of Science, vol 2. University of Minnesota Press, Minneapolis, pp 3-36

Paletschek S (2002) Die Erfindung der Humboldtschen Universität. Historische Anthropol 10(2):183-205

Pereira G, Funtowicz SO (2006) Knowledge representation and mediation for transdisciplinary frameworks: tools to inform debates, dialogues \& deliberations. Int J Transdiscipl Res 1(1):34-50

Piaget J (1968) Genetic epistemology. Columbia University Press, New York, NY

Piaget J (1972) The epistemology of interdisciplinary relationships. In: Apostel L, Berger G, Briggs A, Michaud G (eds) Interdisciplinarity: Problems of teaching and research in universities. OECD, Paris, pp 127-139

Pielke RA Jr (2007) The honest broker: making sense of science in policy and politics. Cambridge University Press, Cambridge

Polk M (2014) Achieving the promise of transdisciplinarity: a critical exploration of the relationship between transdisciplinary research and societal problem solving. Sustain Sci 9(4):439-451

Qi F (2017) On the historical from of academic freedom and the chinese context. Renmin Univ China Educ J 2:003

Ramirez FO, Meyer JW, Lerch J (2016) World society and the globalization of educational policy. In: Mundy K, Green A, Lingard B, Verger A (eds) The handbook of global education policy. Wiley, Chichester, pp 43-63 
Rashdall H (1895) The Universities of Europe in the Middle Ages, vol 1. Clarendon Press, Salerno, Bologna, Paris

Reed BC (2014) The history and science of the Manhattan Project. Springer, Berlin

Rosenhead J, Mingers J (2001) Rational analysis for a problematic world revisited. Wiley, New York, NY

Rüegg W (2004) Themen, Probleme, Erkenntnisse. In: Rüegg W (ed) Geschichte der Universität in Europa Vom 19. Jahrhundert bis zu zweiten Weltkrieg, vol III. C. H. Beck, München, pp 17-42

Samuelson PA (1947) Foundations of economic analysis. Harvard University Press, Cambridge, MA

Schelsky H (1967) Das Zentrum für interdisziplinäre Forschung, Eine Denkschrift. In: Mikat P (ed) Grundzüge einer neuen Universität. Zur Planung einer Hochschule in Ostwestfalen. Bertelsmann Verlag, Gütersloh

Schneidewind U, Feindt PH, Meister HP, Minsch J, Schulz T, Tscheulin J (1997) Institutionelle Reformen für eine Politik der Nachhaltigkeit: Vom Was zum Wie in der Nachhaltigkeitsdebatte. Gaia Ecol Perspect Sci Soc 6(3):182-182

Scholz RW (1994) Muss man den Formalismus beherrschen, um die Formalisten zu schlagen? Umweltforschung quergedacht. In: Daschkeit A, Schröder W (eds) Perspektiven integrativer Umweltforschung und -lehre. Springer, Berlin, pp 309-328

Scholz RW (2000). Mutual learning as a basic principle of transdisciplinarity. In: Scholz RW, Häberli R, Bill A, Welti W (eds) Transdisciplinarity: Joint problem-solving among science, technology and society. Workbook II: Mutual learning sessions. Haffmans Sachbuch, Zürich, pp. 13-17

Scholz RW (2011) Environmental literacy in science and society: from knowledge to decisions. Cambridge University Press, Cambridge

Scholz RW (2017) The normative dimension in transdisciplinarity, transition management, and transformation sciences: New roles of science and universities in sustainable transitioning. Sustainability. https://doi.org/10.3390/su9060991

Scholz RW, Bartelsman EJ, Diefenbach S, Franke L, Grunwald A, Helbing D et al (2018) Unintended side effects of the digital transition: European scientists' messages from a propositionbased expert round table. Sustainability 10(6):2001. https:// doi.org/10.3390/su10062001

Scholz RW, Häberli R, Bill A, Welti M (2000a) Transdisciplinarity: joint problem-solving among science, technology and society. Workbook II: mutual learning sessions, vol 2. Haffmans Sachbuch Verlag, Zürich

Scholz RW, Kaberger T, Koucky M, Engwall Y, Mansson M (2003) Mobilitet och hallbar stadsutveckling —Lundby pa gang. Fallstudie 2002 Göteborgs miljövetenskapliga centrum. Chalmers and Göteborgs Universitet, Gothenburg (ISBN91 8837623 0)

Scholz RW, Lang DJ, Wiek A, Walter AI, Stauffacher M (2006) Transdisciplinary case studies as a means of sustainability learning: Historical framework and theory. Int J Sustain High Educ 7(3):226-251

Scholz RW, Marks D (2001) Learning about transdisciplinarity: Where are we? Where have we been? Where should we go? In: Klein JT, Grossenbacher-Mansuy W, Häberli R, Bill A, Scholz RW, Welti M (eds) Transdisciplinarity: joint problem solving among science, technology, and society. Birkhäuser Verlag AG, Basel, pp 236-252

Scholz RW, Mieg HA, Oswald J (2000b) Transdisciplinarity in groundwater management: towards mutual learning of science and society. Water Air Soil Pollut 123(1-4):477-487

Scholz RW, Roy AH, Brand FS, Hellums DT, Ulrich AE (eds) (2014) Sustainable phosphorus management: a global transdisciplinary roadmap. Springer, Berlin
Scholz RW, Roy AH, Pallas AP, Hellums D (2015) Final Global TraPs Newsletter 13 and follow up activities. https://www. globaltraps.ch/contact.html. Accessed 22 Jan 2019

Scholz RW, Stauffacher M (2009) Von einer Wissenschaft für die Gesellschaft zu einer Wissenschaft mit der Gesellschaft. Psychol Rundschau 60(4):241-242

Scholz RW, Steiner G (2015a) The real type and ideal type of transdisciplinary processes: part I-theoretical foundations. Sustain Sci 10(4):527-544

Scholz RW, Steiner G (2015b) The real type and the ideal type of transdisciplinary processes. Part II-what constraints and obstacles do we meet in practice? Sustain Sci 10(4):653-671. https://doi. org/10.1007/s11625-015-0327-3

Scholz RW, Steiner G (2015c) Transdisciplinarity at the crossroads. Sustain Sci 10(4):521-526

Scholz RW, Tietje O (2002) Embedded case study methods: Integrating quantitative and qualitative knowledge. Sage, Thousand Oaks, CA

Schori S, Krütli M, Stauffacher M, Flüeler T, Scholz RW (2009) Siting of nuclear waste repositories in Switzerland and Sweden. Stakeholder preferences for the interplay between technical expertise and social input. ETH-NSSI Case Study 2008. ETHNSSI TdLab, Zurich

Scott P (2007) From professor to 'knowledge worker': profiles of the academic profession. Minerva 45(2):205-215

Seidl R, Brand F, Stauffacher M, Krütli P, Le QB, Spörri A et al (2013) Science with society in the anthropocene. Ambio 42(1):5-12

Shrestha R, Köckler H, Flacke J, Martinez JM, Van Maarseveen M (2017) Interactive knowledge co-production and integration for healthy urban development. Sustainability 9(11):1945

Siebenhüner B (2018) Conflicts in transdisciplinary research: reviewing literature and analysing a case of climate adaptation in Northwestern Germany. Ecol Econ 154:117-127

Slaughter S, Leslie LL (1999) Academic capitalism: Politics, policies, and the entrepreneurial university. The Johns Hopkins University Press, Baltimore, M.A.

Sprat T (1722) The history of the Royal Society of London: for the improving of natural knowledge, 3rd edn. Samuel Chapman, London

SRC (2019) SRC Global Research Collaboration (GRC). https://www. src.org/program/grc/. Accessed 19 Mar 2020

Stark J (1937) Weisse Juden in der Wissenschaft Das Schwarze Korps, 6

Stauffacher M, Flueeler T, Krueli P, Scholz RW (2008) Analytic and dynamic approach to collaboration: a transdisciplinary case study on sustainable landscape development in a Swiss prealpine region. Syst Pract Action Res 21(6):409-422. https://doi. org/10.1007/s11213-008-9107-7

Stiglitz JE (1999) Knowledge as a global public good. In: Kaul I, Grunberg I, Stern MA (eds) Global public goods: International cooperation in the 21 st century, vol 308 . Orford University Press, New York, N.Y., pp 308-325

Sugiyama M, Deguchi H, Ema A, Kishimoto A, Mori J, Shiroyama H, Scholz RW (2017) Unintended side effects of digital transition: perspectives of Japanese experts. Sustainability 9(12):5. https:// doi.org/10.3390/su9122193

Suh S (ed) (2008) Handbook on input-output analysis in industrial ecology. Edward Elgar, Cheltenham

Teichler U, Arimoto A, Cummings WK (2013) The design and methods of the comparative study. Springer, Cham

Torstendahl R (1993) The transformation of professional education in the nineteenth century. In: Rosenblatt S, Wittrock B (eds) The European and American university since 1800: Historical and sociological essays. Cambridge University Press, Cambridge, pp 109-141

Driessen PPJ et al. (2015) Knowledge for Climate: 2008-2014 (Foundation Knowledge for Climate, Utrecht) 
Verger A (2016) The global diffusion of education orivatization: unpacking and theorizing policy adoption. In: Mundy K, Green A, Lingard B, Verger A (eds) The handbook of global education policy. Wiley, Chichester, pp 64-80

Viale Pereira G, Estevez E, Cardona D, Chesñevar C, Collazzo-Yelpo P, Cunha MA et al (2020) South American expert roundtable: increasing adaptive governance capacity for coping with unintended side effects of digital transformation. Sustainability $12: 718$

von Neumann J, Morgenstern O (1944) Theory of games and economic behavior. Princeton University Press, Princeton

Waddington, C. H., OR in World War 2: Operational Research against the U-Boat (1973) OR in World War 2: operational research against the U-Boat. Elek Science, London

WBGU (2019) WBGU Gutachten: Digitalisierung als Motor für Nachhaltigkeit. Die Bundesregierung, Berlin

Wei IP (2012) Intellectual culture in medieval Paris: theologians and the university, c 1100-1330. Cambridge University Press, Cambridge
Wiener N (1948) Cybernetics or control and communication in the animal and the machine. The MIT Press, Cambridge

Wilson EO (1999) Consilience: the unity of knowledge. Vintage, New York

Wolfensberger M, Lang DJ, Scholz RW (2008) (Re-) Structuring the field of non-energy mineral resource scarcity. Summary of the workshop "Scarce Raw Materials" August 31-September 2, 2007. Davos, Switzerland (43). ETH Zurich: Zurich

Zomer A, Benneworth P (2011) The rise of the university's third mission. In Reform of higher education in Europe, Springer, New York

Zscheischler J, Rogga S (2015) Transdisciplinarity in land use science-a review of concepts, empirical findings and current practices. Futures 65:28-44. https://doi.org/10.1016/j.futur es.2014.11.005

Publisher's Note Springer Nature remains neutral with regard to jurisdictional claims in published maps and institutional affiliations. 